\title{
Benefits of riparian forest for the aquatic ecosystem assessed at a large geographic scale
}

\author{
K. Van Looy ${ }^{(1), \star}$, T. Tormos ${ }^{(2)}$, M. Ferréol(1), B. Villeneuve ${ }^{(1)}$, L. Valette ${ }^{(1)}$, \\ A. Chandesris ${ }^{(1)}$, N. Bougon ${ }^{(2)}$, F. Oraison ${ }^{(1)}$, Y. Souchon ${ }^{(1)}$ \\ Received September 28, 2012 \\ Revised February 7, 2013 \\ Accepted February 10, 2013
}

Key-words: hydromorphological quality, riparian buffer, nutrient reduction, biotic integrity indices

\section{ABSTRACT}

Claimed benefits of riparian forest cover for the aquatic ecosystem include purification, thermal control, organic matter input and habitat provision, which may improve physicochemical and biotic quality. However, these beneficial effects might be flawed by multiple stressor conditions of intensive agriculture and urbanization in upstream catchments. We examined the relationship between riparian forest cover and physicochemical quality and biotic integrity indices in extensive large scale datasets. Measurements of hydromorphological conditions and riparian forest cover across different buffer widths for $59 \times 10^{3}$ river stretches covering $230 \times 10^{3} \mathrm{~km}$ of the French river network were coupled with data for physicochemical and biotic variables taken from the national monitoring network. General linear and quantile regression techniques were used to determine responses of physicochemical variables and biological integrity indices for macroinvertebrates and fish to riparian forest cover in selections of intermediate stress for 2 nd to 4 th order streams. Significant responses to forest cover were found for the nutrient variables and biological indices. According to these responses a $60 \%$ riparian forest cover in the $10 \mathrm{~m}$ buffer corresponds to good status boundaries for physicochemical and biotic elements. For the $30 \mathrm{~m}$ buffer, the observed response suggests that riparian forest coverage of at least $45 \%$ corresponds with good ecological status in the aquatic ecosystem. The observed consistent responses indicate significant potential for improving the quality of the aquatic environment by restoring riparian forest. The effects are more substantial in single-stressor environments but remain significant in multi-stressor environments.

\section{RÉSUMÉ}

\section{Effets bénéfiques des ripisylves pour l'écosystème aquatique discernés à large échelle}

Mots-clés : qualité hydromorphologique, zone tampon
Les avantages présumés de couverts forestiers riverains pour l'écosystème aquatique comprennent la purification, le contrôle thermique, l'apport de matière organique et d'habitats, ce qui peut améliorer la qualité physico-chimique et biotique. Toutefois, ces effets bénéfiques pourraient être atténués par de multiples facteurs de stress de l'agriculture intensive et de l'urbanisation dans les bassins versants en amont. Nous avons examiné la relation entre couvert forestier riverain et la

(1) Irstea, UR MALY, National Research Institute of Science and Technology for Environment and Agriculture, River hydro-ecology unit Onema/Irstea, 5 rue de la Doua, 69626 Villeurbanne, France

(2) French National Agency for Water and Aquatic Environments (Onema), River hydro-ecology unit Onema/Irstea, Lyon Cedex, France

* Corresponding author: kris.van-looy@irstea.fr 
riveraine, réduction nutriments, indices d'intégrité biologique qualité physico-chimique et indices d'intégrité biotique dans de vastes ensembles de données à grande échelle. La mesure des conditions hydromorphologiques et du couvert forestier riverain selon différentes largeurs des zones tampons pour $59 \times 10^{3}$ secteurs de rivière s'étendant sur $230 \times 10^{3} \mathrm{~km}$ du réseau fluvial français ont été couplés avec des données pour les variables physico-chimiques et biotiques prélevés sur le réseau national de surveillance. Des régressions linéaires généralisées et des régressions par quantiles ont servi à déterminer les réponses des variables physico-chimiques et des indices d'intégrité biologique des macroinvertébrés et poissons à la couverture de ripisylve dans les sélections de stress intermédiaire pour les rivières d'ordres 2 à 4 . Des réponses significatives au couvert forestier ont été trouvées pour les nutriments et les indices biologiques. Selon ces réponses, un taux de ripisylve de $60 \%$ dans un corridor de $10 \mathrm{~m}$ correspond aux limites du bon état des variables physico-chimiques et indices biotiques. Pour la zone tampon de $30 \mathrm{~m}$, la réponse observée suggère que la couverture de ripisylve d'au moins $45 \%$ correspond avec le bon état écologique de l'écosystème aquatique. Ces réponses cohérentes indiquent un potentiel important pour l'amélioration de la qualité du milieu aquatique en rétablissant la forêt riveraine. Les effets sont plus importants dans un environnement de pression unique, mais restent quand même importants dans des environnements avec multiple pressions.

\section{INTRODUCTION}

Positive effects of riparian vegetation on the ecological quality of the river by nutrient uptake and habitat provision are still points of debate in scientific journals for the aquatic environment (Mayer et al., 2007; Pärn et al., 2010). Such benefits may include the following: addition of organic matter, diversifying the trophic conditions; thermal regulation by forest canopy cover; structuring of habitat and provision of microhabitat; and buffer for nutrients and pollutant influx to the water course (Lowrance et al., 1984; Lowrance et al., 1997; Wenger et al., 1999). These functions have been evidenced only from local studies with field measurements (Storey and Cowley, 1997; Wallace et al., 1997; Parkyn et al., 2003; Dodds and Oakes, 2006; Rios and Bailey, 2006) and from some larger scale studies in strictly agricultural watersheds (Stewart et al., 2001; Wilson et al., 2008; Arnaiz et al., 2011). The cumulative watershed impact of forested riparian zones on stream nutrient levels is also acknowledged (Newbold et al., 2010; Curie et al., 2011; Wang et al., 2011), but remains poorly understood (Weller et al., 2011). As regards the aquatic ecosystem responses to riparian forest cover, for fish communities some evidence is documented for thermal regulation (Broadmeadow et al., 2011) and for habitat provision (Santoul et al., 2005; Brunke et al., 2008; Elosegi et al., 2010; Hopkins and Whiles, 2011). General beneficial effects of riparian forest cover are observed for periphyton (Bowes et al., 2012), phytoplankton (Hutchins et al., 2010) and wider ranging water quality parameters (Ghermandi et al., 2009). Less uniform responses are found for the macroinvertebrates, for which positive effects are mainly reported for urban areas (Suren and McMurtrie, 2005; Rios and Bailey, 2006; Death and Collier, 2010; Astorga et al., 2011). Inability to identify these outcomes in consistent relationships between the presence and extent of riparian cover and the quality of the aquatic system is often attributed to the context of multiple stressors impacting the river system (Palmer et al., 2010).

Even so, riparian forests are generally acknowledged for their importance in river ecosystem functioning (Gregory et al., 1991), being closely linked to the hydromorphological quality of the river (Van Looy et al., 2008). Accordingly, re-plantation of river margins is the most widely applied restoration technique for rivers throughout Europe, Australia and the USA (Brooks and Lake, 2007; Palmer et al., 2007). Guidelines for these practices are not readily available and are mostly based on providing vegetative buffer strips and terrestrial migration corridors. In this study, we try to assess relationships between the forest cover in the riparian corridor and the anthropogenic pressures that were retrieved from several spatial scales (stretch, hydrologic unit and catchment) in order to assess the impact of the forest cover on 
physicochemical characteristics, and macroinvertebrate and fish metrics reflecting community structure and ecological condition over the French river network. We adopted recent recommendations to advance the use of indicators for running water starting from the correlative approach using large-scale datasets along perturbation gradients (Sandin and Solimini, 2009).

The question underlying our research was: can we observe the claimed benefits of riparian forest cover for the aquatic environment from data at large geographic scale? If so, does the response vary with buffer width, with ecoregion and with pressure conditions, and can it even be identified in environments with multiple stressors? To address these questions, both effects on physicochemical variables and response of the biota can be considered. For this purpose the entire French river network was analysed and national databases of physicochemical and biotic monitoring networks were queried. From the aggregated datasets, a selection of sites was extracted with the same stress conditions at the watershed and local riparian corridor scale and a gradient of riparian forest cover. The response of the biota was measured with the national biotic integrity indices for macroinvertebrate and fish communities.

\section{METHODS}

\section{> HYDROMORPHOLOGICAL AND LAND COVER DATA FOR CATCHMENTS AND RIVER STRETCHES}

For the entire French river network of some $230 \times 10^{3} \mathrm{~km}$, a hydromorphology audit system, SYRAH, was developed (Chandesris et al., 2008), based on a systematic segmentation and assembling of data from three scale levels: the catchment scale, sub-catchments called hydrologic units and the local river stretch. Rivers were subdivided into hydro-morphologically homogeneous stretches based on a splitting that distinguished changes in channel and valley form. Resulting river segments range from $1 \mathrm{~km}$ on average for small streams and up to $20 \mathrm{~km}$ on average for large rivers. Data of the riparian corridor was gathered for the $59 \times 10^{3}$ river stretches in different buffer sizes (valley floor, winter bed, $100 \mathrm{~m}, 30 \mathrm{~m}, 10 \mathrm{~m}$ ). Riparian forest cover was derived from the national geographic database BDTopo IGN ${ }^{\circledR}$. In this vector database (resolution $1.5 \mathrm{~m}$ ), forest polygons are delimited from photo-interpretation of the aerial remotely sensed database BDOrtho IGN ${ }^{\circledR}$. Riparian forest cover is retrieved for each river stretch by calculating the surface areas of forest polygons within the floodplain and two different size buffers of $10 \mathrm{~m}$ and $30 \mathrm{~m}$ for both sides of the river bank. These buffers represent different parts of riverine forests; in the $10 \mathrm{~m}$ buffer, only a small ridge of trees that gives canopy cover to the aquatic system is identified, the cover of the $30 \mathrm{~m}$ buffer delimits the riparian forest in the strict sense, and the winter bed forest cover encompasses all kinds of alluvial forests along the river.

Hydromorphological and geographical data for river basins and stretches was gathered at the same sub-catchment and river stretch scale (Table I). For each river stretch, land cover was calculated at the catchment scale and for the local valley floor, using the CORINE Land Cover 2000 map (CLC, resolution $100 \mathrm{~m}$ ). This is a vector map, drawn from satellite imaging at a scale of 1:100 000, with a minimum polygon size of 25 ha (http://terrestrial.eionet.europa. eu/CLC2000). The CLC is based on a hierarchical standard nomenclature with three levels: 5 broad land cover categories at level 1 (1: artificial surfaces, 2: agricultural areas, 3: forests and semi-natural areas, 4: wetlands and 5: waterbodies). For the land use in the riparian corridor, information was gathered from the digitally available BD Topo IGN ${ }^{\circledR}$ topographic maps.

\section{> WATER PHYSICOCHEMICAL DATA AND BIOTIC INTEGRITY INDICES}

Data for physicochemical and biotic variables over the last decade were selected from the national monitoring network, consisting of 1949 sites evenly distributed over the French ecoregions and river types. The information from the sites was collated with the hydromorphological geodata for the river stretch to which the site belonged and with its upstream catchment 
Table I

Environmental variables of the SYRAH database to detect hydromorphological alterations at the different spatial scales that are collated to the individual river stretches and survey sites.

\begin{tabular}{|c|c|}
\hline \multicolumn{2}{|l|}{ Watershed } \\
\hline Ratio_ARTI & $\begin{array}{l}\text { percentage cover of urban land use class in CORINE land cover data } \\
\text { of the sub-catchments }\end{array}$ \\
\hline Ratio_AGRI & $\begin{array}{l}\text { percentage cover of intensive agricultural CORINE land cover classes } \\
\text { of the sub-catchments }\end{array}$ \\
\hline Ratio_NATUR & $\begin{array}{l}\text { percentage cover of near-natural CORINE land cover classes data } \\
\text { of the sub-catchments }\end{array}$ \\
\hline Drainage & percentage of drained land in watershed \\
\hline Irrigation & percentage of irrigated land in watershed \\
\hline Erosion & percentage of erosion-sensitive land in watershed \\
\hline \multicolumn{2}{|l|}{ River stretch } \\
\hline Discharge_spec & annual peak discharge estimate \\
\hline Channel straightening & percentage of straight reaches over the stretch, weighted by river type \\
\hline Bars & number of lateral bars over the stretch, divided by river length \\
\hline Dams/weirs & number of weirs/dams per stretch, divided by river length \\
\hline Bridges & number of river crossing bridges per stretch, divided by river length \\
\hline \multicolumn{2}{|l|}{ Alluvial plain } \\
\hline VegFP & $\begin{array}{l}\text { percentage cover of forest patches over the alluvial } \\
\text { plain of the river stretch }\end{array}$ \\
\hline infraVF & $\begin{array}{l}\text { percentage cover of infrastructure over the alluvial plain } \\
\text { of the river stretch }\end{array}$ \\
\hline DikesFP & length of flood protection levees per stretch, divided by river length \\
\hline ConWat & $\begin{array}{l}\text { percentage cover of connected standing waters over the alluvial plain } \\
\text { of the river stretch }\end{array}$ \\
\hline UnconWat & $\begin{array}{l}\text { percentage cover of disconnected standing waters over the alluvial plain } \\
\text { of the river stretch }\end{array}$ \\
\hline \multicolumn{2}{|l|}{ River bank } \\
\hline Veg30 m & $\begin{array}{l}\text { percentage cover of forest patches for the } 30 \mathrm{~m} \text { riparian buffer } \\
\text { of the river stretch }\end{array}$ \\
\hline Veg10 m & $\begin{array}{l}\text { percentage cover of forest patches for the } 10 \mathrm{~m} \text { riparian buffer } \\
\text { of the river stretch }\end{array}$ \\
\hline InfraFP & $\begin{array}{l}\text { percentage cover of infrastructure over riparian buffer of three river widths } \\
\text { of the stretch }\end{array}$ \\
\hline Urb100m & $\begin{array}{l}\text { percentage cover of urbanisation for the } 100 \mathrm{~m} \text { riparian buffer } \\
\text { of the river stretch }\end{array}$ \\
\hline
\end{tabular}

land cover. As these sites are selected for a biotic quality assessment representative for the local water body (which is a larger spatial unit than the hydromorphological stretch), this attribution of characteristics from the local stretch is reliable for our robust analysis. For the monthly recorded water chemistry data, the following variables were retained for our analysis: temperature, oxygen and nutrients (total nitrogen, ammonium, nitrite and nitrate, total phosphorus, orthophosphates and BOD). Only annual mean values were retained in the response analysis, as the averaged data can cover the impact of the riparian corridor on the aquatic system, whereas the more exceptional loads of nutriments (90th percentile) cannot be directly affected by the local riparian environment.

For macroinvertebrates, annual survey data are available per site. For fish, a standardised protocol of biannual measurements has been in place for the last 8 years. The macroinvertebrates were evaluated using the IBGN index (Indice Biologique Global Normalisé) (A.F.N.O.R. 1992). The IBGN is a combination of two metrics: the total number of taxa (14 classes at family level) and the faunistic indicator group representing the presence or absence of 39 indicator taxa, grouped into nine sensitivity classes. The index is sensitive to pollution (especially eutrophication) and to general degradation (including habitat alteration). For its application to large geographical scale analysis based on the national level datasets, see also Wasson et al. (2010). For fish, a standard electrofishing protocol was carried out during low-flow periods (May-October) to collect information about fish assemblages in the 
monitoring network. The biotic index used in the evaluation of the ecological quality was the French fish-based index for the assessment of river health (IPR) (Oberdorff et al., 2002). Both for macroinvertebrates and for fish the median index values for the years since 2003 were selected from the database for each site.

\section{>STRESSOR GRADIENT DEFINITION AND SELECTION OF HOMOGENEOUS STRESSOR SITES}

The complexity of the processes involved in nutrient reduction in spatial and temporal context demands the selection of datasets homogeneous in both environmental and anthropogenic stressor conditions to infer the role of riparian forest cover in the nutrient cycling. Transfers to and through water courses may be influenced by topography, climate, soil type, bedrock and water flow. We assumed that for areas in which these factors are quite homogeneous, nutrient transfers are similar, and so are temporal patterns of concentration in water courses. The application of hydro-ecoregions as homogeneous spatial units for this kind of analysis has already been successfully demonstrated in several studies (Wasson et al. 2010; Sauquet and Catalogne 2011; Gauroy and Carluer, 2011).

Preliminary to the selection of survey sites, the main anthropogenic stressors to riparian forest fragmentation were explored over the entire river network to allow the detection of datasets homogeneous in stressor conditions.

For the selection of comparable survey site subsets, only sites on second to fourth Strahler order streams were retained, as the size influences the biochemical processing (Montreuil et al., 2010). For response testing of respectively the physicochemical variables and the biotic elements, different selections were imposed to derive subsets homogeneous in stream type and anthropogenic disturbance. For the impact on physicochemical elements, it was possible to work within the six types of the national chemical typology of running waters (Bougon and Ferréol, 2010). This typology of French rivers for general physicochemical variables is based on two main descriptors; alkalinity, which corresponds primarily to regional geology, and nutrient conditions, corresponding to an altitudinal or distance-to-source gradient.

The response testing of biotic elements was executed within ecoregion subsets. The French hydro-ecoregion (HER) classification comprises 22 geographical entities in which stream and river ecosystems should exhibit common characteristics. Geology, relief and climate are the determinants for the hydro-ecoregion delimitation in France (Wasson et al., 2002). The HERs provide a framework for grouping data in terms of natural river features and human activities. The applied biotic integrity indices further integrate river typology aspects in the assessment, since they are defined as the deviation from type-specific reference conditions. Also, for both these biotic indices and the physico-chemical variables, standards are set for good ecological status (NOR: DEVO1001032A). These normative boundaries can be reproduced if we observe significant relationships with riparian forest presence to identify minimal riparian forest cover to achieve good ecological status.

After primary elimination of ecoregions with too few sites with homogeneous stressor conditions, the two largest HERs were selected for the analysis of biotic responses (Figure 1). The Calcareous Plains ecoregion HER9 covers $25 \%$ of France; the landscape comprises lowlands and plains, with low-energy streams. The land cover is characterised by a densely urbanised area around Paris and sparsely populated rural areas with intensive agricultural land use mainly for crops. The adjacent Calcareous Front ecoregion HER10 has a more submountainous geography with a contrasting land use of forests and agricultural use for livestock production (grassland).

\section{STATISTICAL ANALYSES}

A preliminary data exploration was executed using principal component analysis (PCA) to eliminate redundancy in variables and detect main stressors for hydromorphological characteristics of the river stretches - including riparian forest cover - on the entire river network 


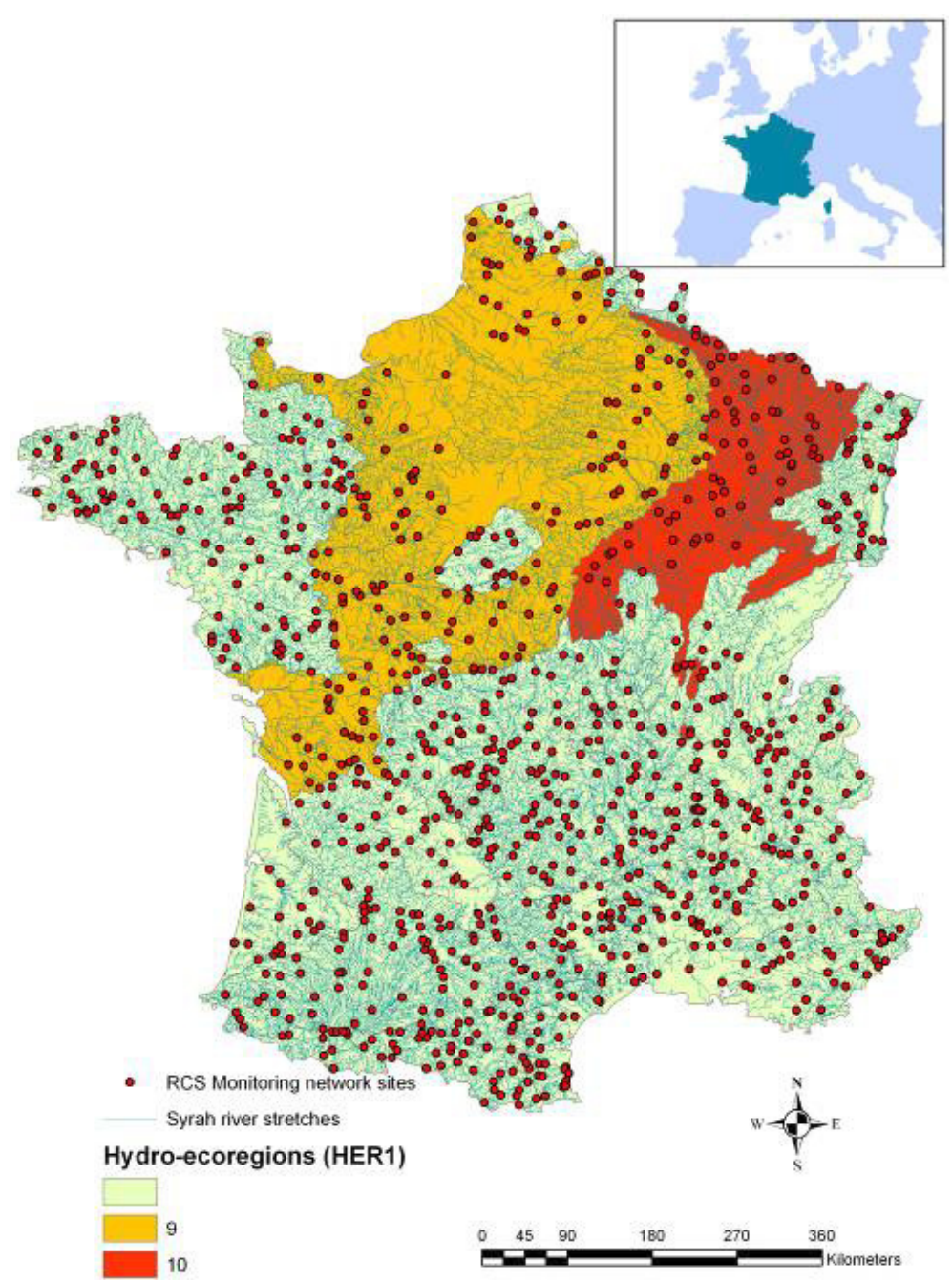

Figure 1

The studied French river network (the $230 \times 10^{3}$ river $\mathrm{km}$ in $59 \times 10^{3}$ Syrah stretches) and the selected monitoring network sites (national surveillance monitoring network RCS), and with bold contour the two ecoregions (HER 9 and 10) selected for the response of the aquatic communities.

of $59 \times 10^{3}$ river stretches present in the SYRAH geodatabase. Spearmann correlation testing between riparian forest cover and the selected variables from the PCA determined main stressors for the hydromorphological character. Elimination of upper and lower quantiles of these main stressors gave a selection of intermediate-pressure sites.

Within this selection, responses of the physicochemical variables to forest cover were investigated per chemical type. This testing was done individually per type, as we were interested in type-specific responses.

For the biotic responses a further selection of sites with homogeneous intermediate pressure within specific ecoregions was executed. These selections were assumed to show no relation of the relevant pressures to the riparian forest cover; this needed checking by correlation analysis between the stressors and riparian forest cover in the selected population using Spearman ranking tests. Further correlation testing between ecoregions was performed to see whether geographical differences were present for the responses, and in particular to test for multi-stressor environment effects. The presence of multiple stressors may outweigh the positive impact of the riparian canopy.

The response testing was done with linear regression techniques, first for the physicochemical variables within the distinct chemical types and secondly for the physicochemical and 
biological variables in the ecoregions. As there was a range of unmeasured factors that were limiting for the response, quantile regression was used to obtain a better estimation and interpretation of the relationship under these circumstances, as this technique can more clearly distinguish changes in heterogeneous distributions (Cade and Noon, 2003). It is also useful to estimate a range of quantiles rather than basing an analysis on only the mean or a single selected quantile (Cade and Noon, 2003). Here, we investigated the significance and concordance in the responses for the median and upper quantiles (50th, 75th, 90th and 95th), to see whether a general response for means as a conformity in the response of extreme values and thus an overall response was present. For the graphic presentation of the quantile regression results, the additive models for conditional quantile functions were used, as they provide an attractive framework to focus on features of the response beyond its central tendency (Koenker, 2010).

Finally, to test whether the outcomes are not biased by hydrological processes like dilution, a verification of the results with respect to flow regime was executed. The annual peak flow estimation (Q95 annual daily discharge, estimation to bankfull and effective discharge according to Leopold (1994)) was determined for each stretch, based on extrapolation models for the national gauging stations (Snelder, Lamouroux, Leathwick et al., 2009; Sauquet and Catalogne, 2011). A multivariate regression analysis was performed to enable consideration of respective predictive power to nutrient reductions for the riparian forest cover and the flow regime. All factor analyses, Spearman ranking correlation tests and linear regressions were performed in Statistica (Statsoft, 2010); the quantile regression analysis was performed with Quantreg in $R$ (Koenker, 2010).

\section{RESULTS}

\section{> STRESSOR GRADIENT IDENTIFICATION}

Data exploration with factor analysis for riparian forest cover on the entire French river network revealed significant responses to urbanisation and agriculture in the riparian corridor and the catchment. As no geographical or hydrological variables were included, the PCA (Figure 2) only explained a part of the broad hydromorphological variation over the river network. However, some clear distinctions between selected variables were observed. The first axis (eigenvalue 3.4, expl. 16.19\%) reflected the naturalness of the stretch, whereas the second axis (eigenvalue 2.8, expl. 13.3\%) discriminated between the stressors, opposing agricultural versus urban origin of alterations, and catchment versus local stressors. The riparian forest cover showed low values for this second axis and hence no distinction for forest fragmentation can be inferred for its origin; whether stressors are agricultural or urban, local or catchment-induced.

The stressors of intensive agricultural land use and urbanisation in the catchment show strongest opposed position to the riparian forest cover on the first PCA axis. Our dataset furthermore clearly demonstrates the prevailing multi-stressor environments; with average values of $39 \%$ intensive agriculture and $5.6 \%$ urban land cover for the catchments of the monitoring network sites, and a significant correlation (Spearman $R=0.24$ ) between these stressors. The urban and agricultural stressors also showed significant correlations with riparian forest cover for the local variables; for the urbanisation in a $100 \mathrm{~m}$ buffer $R=-0.12$, $p<0.01$, and for river channel straightening $(R=-0.15, p<0.01)$. This last correlation corresponds to impairment mainly by agricultural land use, mostly exercised on the smaller rivers (Strahler order is at the opposite end of the axis). For these identified main stressors on the riparian forest, the selection of stretches with intermediate stress on the riparian forest was executed with boundaries of 2-10\% urbanisation, whereas for the impairment by agricultural land use more gradual responses were found, and values between $20 \%$ and $50 \%$ cover in the watershed corresponded to intermediate stress conditions. 


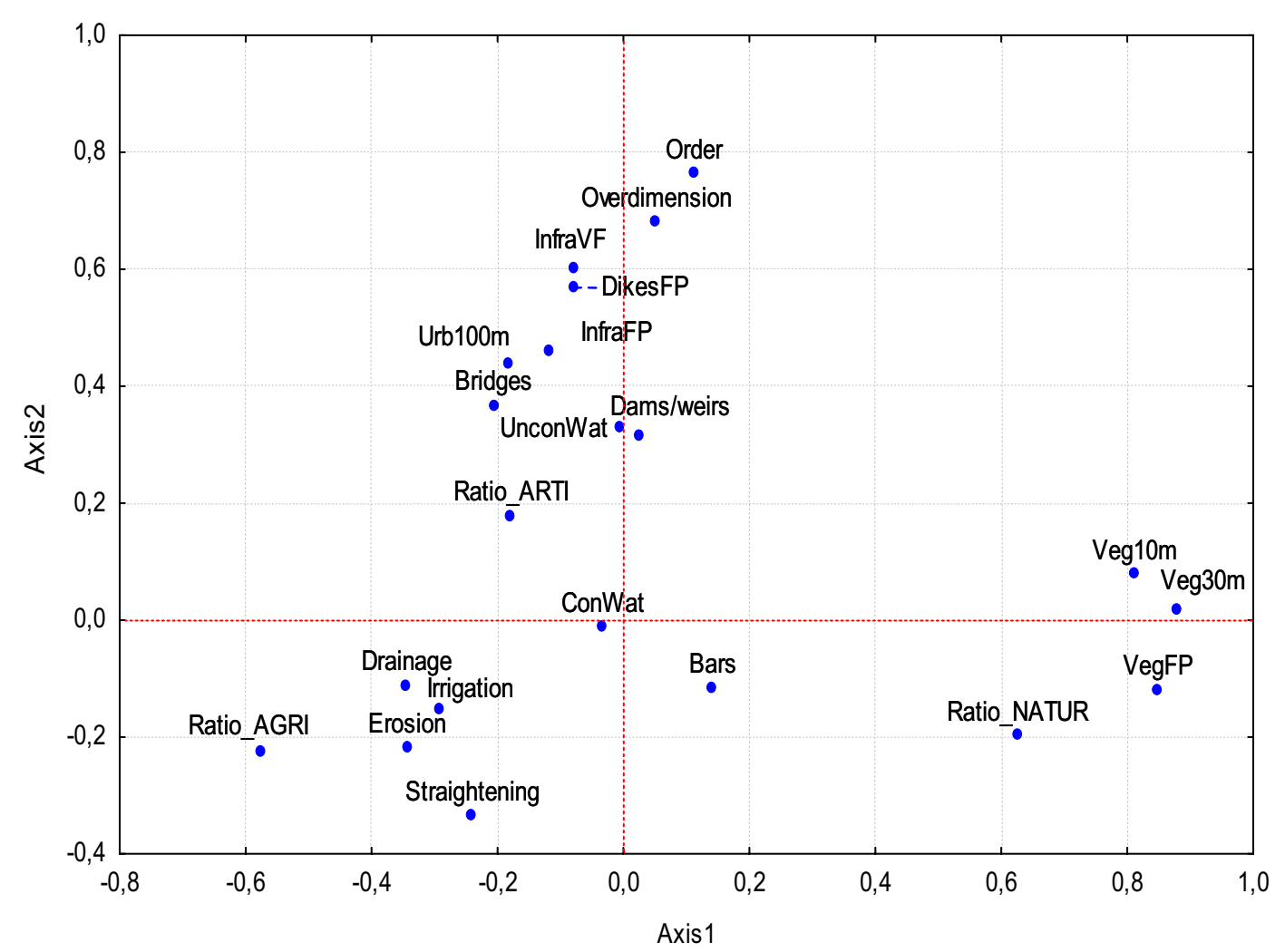

Figure 2

First two axes of the PCA for the riparian forest cover and the other hydromorphological characteristics for all the French river stretches. For the code description of the environmental variables see Table I.

\section{> RIPARIAN-WATER CHEMISTRY RELATIONSHIPS}

For two chemical types of alkaline streams $(\mathrm{H} 1$ and $\mathrm{H} 2)$ of upstream and middle stream regions, correlations (Spearman ranking significance $<0.05$ ) between agricultural land use and riparian forest cover for the selected intermediate stress sites impeded the use of these types in the analysis. For the four other chemical types, no significant correlation of riparian forest cover with the urban and agricultural land cover in the catchment was observed $(p<0.05)$. For the analyses, 445 sites of the lowland alkaline type H3, and the more acidic types S1, S2 and S3 corresponding to the intermediate stress conditions of agriculture and urbanisation were retained.

For nutrients a range of significant responses was present (Table II), whereas for oxygen and temperature no responses were observed. For these last two wide-ranging variables, the data gathered in the national monitoring network did not allow these kinds of correspondence analyses. For the significant nutrient responses, the different forms of nitrogen and phosphorus showed lower values with higher riparian forest cover.

The responses were comparable among chemical types, although nitrite and total phosphorous showed more consistent responses across all types than nitrate and orthophosphate. The absence of an ammonium response in the hard water type was as expected, as this cation is less abundantly present under more alkaline conditions. No consistent differences were observed in the responses for the different buffer widths investigated.

\section{> RESPONSES OF BIOTA AND NUTRIENTS TO RIPARIAN FOREST COVER IN THE ECOREGIONS}

Two largest ecoregions (Calcareous plains HER9 and Calcareous front HER10 covering a major part of the north of France) were retained in the selection, as either too few sites with 
Table II

Slope (b), explained variance $\left(\mathrm{R}^{2}\right)$ and significance (p) of the linear regressions for nutrients in relation with riparian forest cover in buffers of $10 \mathrm{~m}$ and $30 \mathrm{~m}$ for the different chemical types.

\begin{tabular}{|c|c|c|c|c|c|c|c|c|c|c|c|c|}
\hline & \multicolumn{6}{|c|}{ Lowland alkaline rivers $\mathrm{H} 3$} & \multicolumn{6}{|c|}{ Non-alkaline upland rivers S1 } \\
\hline & \multicolumn{3}{|c|}{ Veg10 m } & \multicolumn{3}{|c|}{ Veg30 m } & \multicolumn{3}{|c|}{ Veg10 m } & \multicolumn{3}{|c|}{ Veg30 m } \\
\hline & $b$ & $R^{2}$ & $p$ & $b$ & $R^{2}$ & $p$ & $\bar{b}$ & $R^{2}$ & $\bar{p}$ & $b$ & $\overline{R^{2}}$ & $\bar{p}$ \\
\hline Ammon & -0.04 & 0.01 & 0.92 & 0.01 & 0.01 & 0.68 & -0.31 & $0.12^{\star}$ & 0.02 & -0.33 & $0.21^{\star}$ & 0.004 \\
\hline Nitrite & -0.20 & $0.13^{\star}$ & 0.01 & -0.02 & 0.01 & 0.92 & -0.27 & $0.21^{*}$ & 0.008 & -0.17 & 0.03 & 0.43 \\
\hline Nitrate & -0.22 & $0.20^{*}$ & 0.003 & -0.21 & $0.19^{\star}$ & 0.009 & -0.25 & 0.09 & 0.09 & -0.25 & $0.14^{\star}$ & 0.01 \\
\hline Phosphorus total & -0.22 & $0.12^{*}$ & 0.03 & -0.19 & $0.11^{\star}$ & 0.03 & -0.30 & $0.20^{*}$ & 0.005 & -0.28 & $0.19^{\star}$ & 0.005 \\
\hline \multirow[t]{2}{*}{ Orthophosphate } & -0.09 & 0.03 & 0.15 & -0.18 & 0.02 & 0.58 & -0.35 & $0.11^{*}$ & 0.05 & -0.37 & $0.12^{*}$ & 0.02 \\
\hline & \multicolumn{6}{|c|}{$N=58$ sites } & \multicolumn{6}{|c|}{$N=65$ sites } \\
\hline
\end{tabular}

\begin{tabular}{|c|c|c|c|c|c|c|c|c|c|c|c|c|}
\hline & \multicolumn{6}{|c|}{ Non-alkaline middle courses $\$ 2$} & \multicolumn{6}{|c|}{ Non-alkaline lowland rivers S3 } \\
\hline & \multicolumn{3}{|c|}{ Veg10 m } & \multicolumn{3}{|c|}{ Veg30 m } & \multicolumn{3}{|c|}{ Veg10 m } & \multicolumn{3}{|c|}{ Veg30 m } \\
\hline & $\bar{b}$ & $R^{2}$ & $\bar{p}$ & $\bar{b}$ & $R^{2}$ & $\bar{p}$ & $\bar{b}$ & $\overline{R^{2}}$ & $\bar{p}$ & $\bar{b}$ & $R^{2}$ & $\bar{p}$ \\
\hline Ammc & -0.11 & $0.14^{\star}$ & 0.002 & -0.13 & $0.16^{\star}$ & 0.001 & -0.13 & $0.12^{*}$ & 0.02 & -0.11 & 0.04 & 0.24 \\
\hline Nitrite & -0.16 & $0.15^{\star}$ & 0.002 & -0.15 & $0.11^{*}$ & 0.02 & -0.13 & $0.12^{*}$ & 0.02 & -0.13 & $0.16^{*}$ & 0.004 \\
\hline Nitrate & -0.12 & 0.04 & 0.16 & -0.09 & 0.03 & 0.74 & -0.11 & $0.11^{*}$ & 0.04 & -0.10 & $0.11^{*}$ & 0.05 \\
\hline \begin{tabular}{|l|} 
Phosphorus total \\
\end{tabular} & -0.18 & $0.18^{\star}$ & 0.003 & -0.01 & 0.01 & 0.98 & $\mid-0.16$ & $0.15^{\star}$ & 0.01 & -0.18 & $0.19^{\star}$ & 0.002 \\
\hline \multirow[t]{2}{*}{ Orthophosphate } & -0.25 & $0.22^{*}$ & 0.0006 & -0.08 & 0.03 & 0.47 & -0.05 & 0.09 & 0.06 & -0.06 & 0.04 & 0.16 \\
\hline & \multicolumn{6}{|c|}{$N=177$ sites } & \multicolumn{6}{|c|}{$N=65$ sites } \\
\hline
\end{tabular}

intermediate stress $(<50)$, or correlations between riparian forest cover and the stressors were present in most ecoregions. The riparian forest cover showed no correlation with the identified stressors of percentage of urbanisation or intensive agriculture in the watershed (Spearman ranking $R$ for riparian forest in $10 \mathrm{~m}$ buffer with percentage intensive agriculture and urban area in HER9 were -0.06 and 0.07 and for HER10: -0.08 and 0.05 ). For ecoregion HER9 the multi-stressor context is more important, as there was a significantly higher agricultural land use (average 45\%) than in the HER10 selection (average 34\%, SD 11, $t$-test value (Wilcoxon $Z$ ) 4.6, $p<0.0001$ ) with a similar urbanisation.

Also, for this ecoregion scale analysis, some significant responses for nutrient elements were observed (Table III). The quantile regression results of the median and the 75-quantile regression for the $10 \mathrm{~m}$ and $30 \mathrm{~m}$ buffer had the same significance for the identified responses (shown as example for phosphorus in Table IV and Figures 3 and 4).

Where the linear regression showed significant responses for macroinvertebrate average integrity scores both in HER9 and 10 (Table V), the responses proved stable in all quantiles in the HER10 only. For the fish index, the regressions showed significance only for HER10, thus confirming the difference between the biotic response for HER9 and 10 (Table VI).

In the analysis for dilution effects, discharges in the ecoregion HER9 selection were significantly correlated to nutrient concentrations for orthophosphates $(R-0.33)$, nitrites $(R-0.25)$ and nitrates $(R-0.23)$. The multiple regression with riparian forest cover in the $10 \mathrm{~m}$ buffer and discharge (Table VII) added some 10\% explained variance for orthophosphate mean concentration (multiple regression $R^{2}=0.245$, in contrast to simple regression for riparian forest cover $R^{2}=0.147$ ). No significant intra-variable effect was present. In the ecoregion HER10 discharge correlated strongest to nitrites $(R-0.33)$, ammonium $(R-0.27)$ and nitrates $(R-0.23)$. Here again, the multiple regression with riparian forest cover in the $10 \mathrm{~m}$ buffer and discharge (Table VII) showed no intra-effects and added some 10\% explained variance for nitrites mean concentration (multiple regression $R^{2}=0.235$, in contrast to simple regression for riparian forest cover $R^{2}=0.1$ ). 


\section{Table III}

Linear regression results for the physical-chemical variables in relation with riparian forest cover in buffers of $10 \mathrm{~m}$ and $30 \mathrm{~m}$ for the selected hydro-ecoregions.

\begin{tabular}{|c|c|c|c|c|c|c|c|c|}
\hline & \multirow{2}{*}{\multicolumn{2}{|c|}{ Calcareous plains }} & \multicolumn{2}{|c|}{\begin{tabular}{|c} 
hydro-ecoregion \\
HER9 \\
\end{tabular}} & \multicolumn{2}{|c|}{ Calcareous front } & \multicolumn{2}{|c|}{$\begin{array}{c}\text { hydro-ecoregion } \\
\text { HER10 }\end{array}$} \\
\hline & & & \multicolumn{2}{|c|}{ Veg30 m } & \multicolumn{2}{|c|}{ Veg10 m } & \multicolumn{2}{|c|}{ Veg30 m } \\
\hline & $\bar{b}$ & $R^{2}$ & $\bar{b}$ & $\overline{R^{2}}$ & $\bar{b}$ & $\frac{R^{2}}{2}(1)$ & $\bar{b}$ & $\overline{R^{2}}$ \\
\hline N-Kjeldahl & -0.24 & 0.03 & \begin{tabular}{|l|}
-0.32 \\
\end{tabular} & 0.02 & -0.14 & $0.15^{*}$ & -0.04 & 0.02 \\
\hline Ammonium & -0.13 & 0.02 & -0.08 & 0.01 & -0.17 & $0.17^{\star}$ & -0.18 & 0.08 \\
\hline Nitrite & -0.13 & $0.15^{\star}$ & -0.18 & 0.07 & -0.13 & 0.06 & -0.21 & 0.02 \\
\hline Nitrate & -0.16 & 0.08 & -0.14 & 0.06 & -0.03 & 0.02 & \begin{tabular}{|c|}
-0.03 \\
\end{tabular} & 0.01 \\
\hline Phosphorus total & -0.25 & $0.19^{*}$ & -0.30 & $0.21^{*}$ & -0.14 & $0.19^{*}$ & -0.14 & $0.18^{*}$ \\
\hline \multirow[t]{2}{*}{ Orthophosphate } & -0.25 & $0.21^{*}$ & -0.28 & $0.22^{*}$ & -0.13 & $0.13^{*}$ & \begin{tabular}{|l|}
-0.13 \\
\end{tabular} & $0.11^{*}$ \\
\hline & \multicolumn{4}{|c|}{$N=113$ sites } & \multicolumn{4}{|c|}{$N=93$ sites } \\
\hline
\end{tabular}

\section{Table IV}

Total phosphorus and orthophosphate quantile regression results for riparian forest in $10 \mathrm{~m}$ buffer in the hydro-ecoregion HER9. Tau main effects for median (0.5) and upper quartile (0.75).

\begin{tabular}{|l|c|c|c|c|}
\cline { 2 - 5 } \multicolumn{1}{c|}{} & Value & Std. Error & $t$ value & $\operatorname{Pr}(>|t|)$ \\
\hline $\begin{array}{l}\text { Total P } \\
\text { tau: } \mathbf{0 . 5}\end{array}$ & -0.0005 & 0.0002 & -2.8 & $0.005^{*}$ \\
\hline tau: $\mathbf{0 . 7 5}$ & -0.0008 & 0.0003 & -2.6 & $0.011^{*}$ \\
\hline $\begin{array}{l}\text { Orthophosphate } \\
\text { tau: } \mathbf{0 . 5}\end{array}$ & -0.0010 & 0.0003 & -3.0 & $0.003^{*}$ \\
\hline tau: $\mathbf{0 . 7 5}$ & -0.0009 & 0.0004 & -2.2 & $0.032^{*}$ \\
\hline
\end{tabular}

\section{DISCUSSION}

\section{> RIPARIAN FOREST COVER - AQUATIC ECOSYSTEM RELATIONSHIP}

In literature, large scale inferences of a significant relationship of riparian forest cover with biotic integrity are weakly quantified or show loose correspondence (Allan, 2004; Wasson et al., 2010; Arnaiz et al., 2011), often owing to the difficulty of retrieving accurate land cover data for the riparian corridor zone (Tormos et al., 2011). Here, we observed consistent responses to riparian forest cover in the selected datasets for nutrients and for biotic integrity indices. The results are consistent, as the same responses were observed over different selections, both over the chemical types and in the ecoregions. For the strongest responses of physicochemical parameters and biotic integrity indices, similar regression slopes were obtained and thus identical indications for ranges of riparian forest cover necessary for a good ecological functioning. Furthermore we tested for potential bias for our results caused by dilution effects. As the nutrients are negatively correlated to discharge of the selected stretches, indeed a dilution effect is observed. Yet, this effect does not interfere in the observed relationship with riparian forest cover, as evidenced in the correlation and multivariate regression results. The flow regime information adds significantly to the explained variance of nutrient concentration, yet with no overlap between the discharge and riparian forest cover predictor variables.

In addition, the responses were determined with different statistical approaches; the quantile regression analysis corroborated the responses, showing the presence of the response over the entire gradient, and not merely for the mean values. Quantile regression provides a more complete picture of the relationships between variables missed by other regression techniques, and is especially efficient for datasets with many unmeasured explanatory factors (Cade and Noon, 2003), as is the case for our river quality data. Where the general linear regression pointed out a correlation between forest cover and the macroinvertebrate integrity in ecoregion HER9, the detailed analysis of the response in quantile regression revealed the difference in the responses between the ecoregions. This illustrates the useful application of 

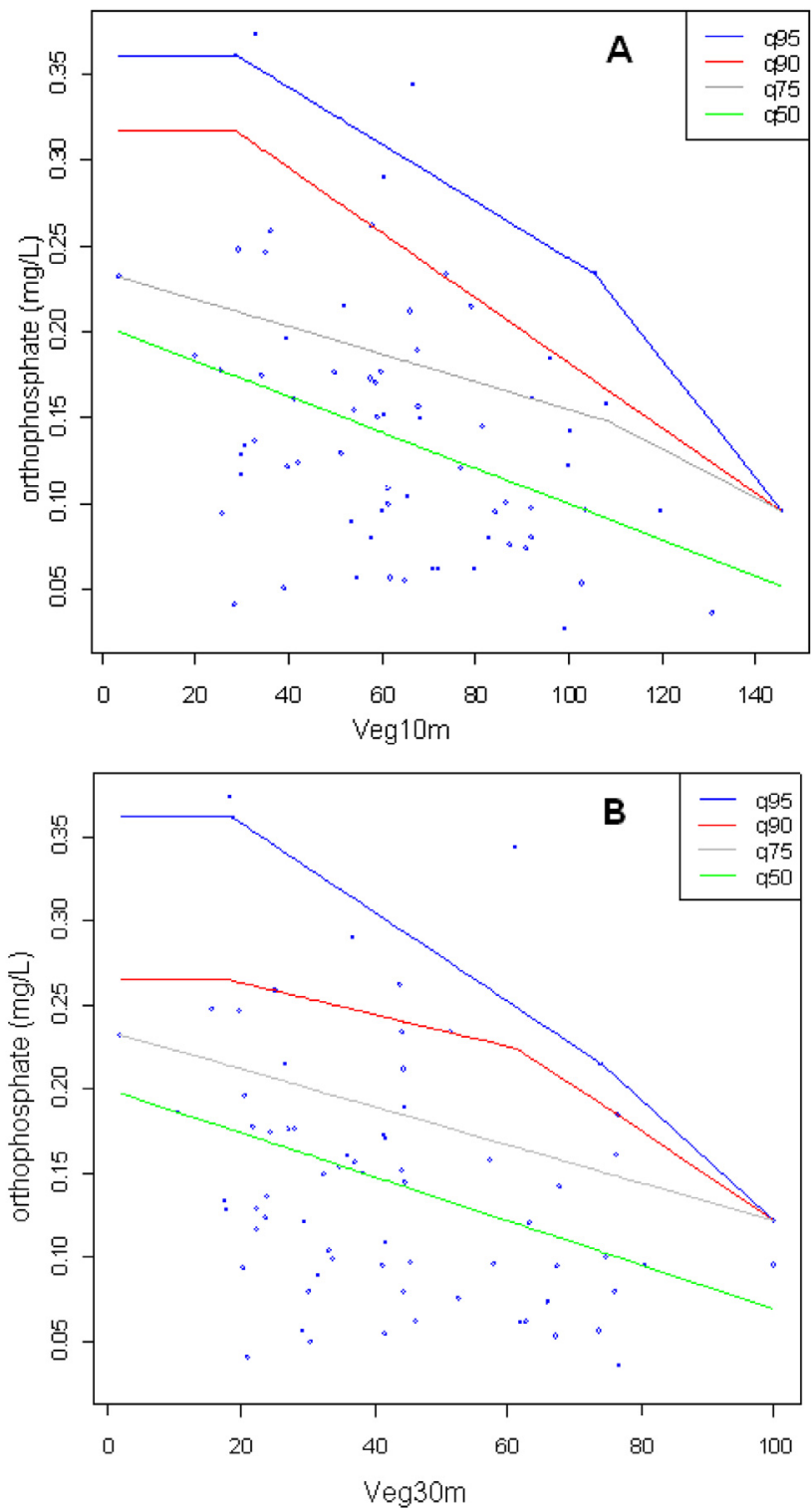

Figure 3

Presentation with additive model for conditional quantile functions (quantiles q50, q75, q90, q95, from RQSS, Koenker 2010) for orthophosphate response to riparian forest cover of the $10 \mathrm{~m}(\mathrm{Veg} 10 \mathrm{~m}, \mathrm{~A})$ and $30 \mathrm{~m}$ (Veg30 m, B) buffer for the sites (points) in ecoregion HER9. We note that for the $10 \mathrm{~m}$ buffer the values can exceed $100 \%$ cover due to the calculation (omitting water part in buffer surface calculation, but not in forest cover).

the quantile regression technique to support the analysis of heterogeneous distributions for multiple stressor environments.

The results also show consistency with other studies. From a regional-scale river network nutrient modelling study in the ecoregion HER9, a significant diminution of nutrient load was attributed to riparian forest cover (Curie et al., 2011). The observed responses are also in line with records for other parts of the world (Storey and Cowley, 1997; Stewart et al., 2001; Meador and Goldstein, 2003; Arnaiz et al., 2011). Although no process-based experimental set up is used, and no site-specific information of forest cover to the biotic measurements is included, the data presented here over a large geographical scale yields consistent proof for the stated hypotheses of this functional benefit of riparian forests at the terrestrial-aquatic 


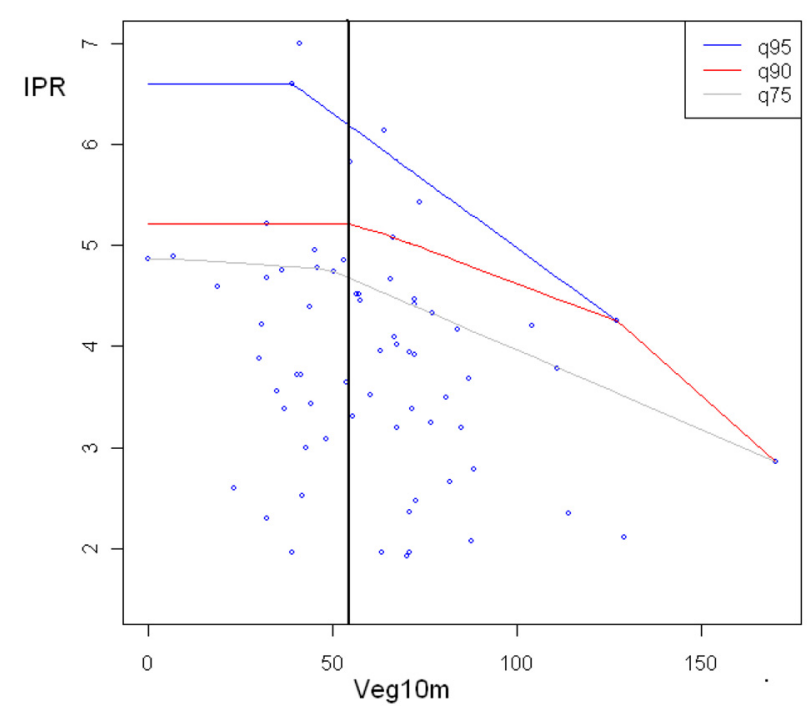

\section{Figure 4}

Additive model for conditional quantile functions (Koenker 2010) applied to the fish biotic index IPR response to riparian forest cover of the $10 \mathrm{~m}$ buffer $(\mathrm{Veg} 10 \mathrm{~m})$ in the ecoregion HER10. The upper quantiles q75, q90 and q95 functions are projected to detect boundary conditions at inflection points of the quantile regression lines.

\section{Table $V$}

Significance of the linear regressions for the biotic integrity indices of macroinvertebrates (IBGN) and fishes (IPR) in relation with riparian forest cover in buffers of $10 \mathrm{~m}$ and $30 \mathrm{~m}$ for the different hydroecoregions.

\begin{tabular}{|l|c|c|c|c|}
\hline \multirow{4}{*}{ Calcareous } & \multicolumn{2}{|c|}{ Plains hydro-ecoregion } & \multicolumn{2}{c|}{ Calcareous Front hydro-ecoregion } \\
\cline { 2 - 5 } & \multicolumn{3}{|c|}{ HER9 } & \multicolumn{2}{c|}{ HER10 } \\
\cline { 2 - 5 } & \multicolumn{2}{|c|}{ Veg10 m } & \multicolumn{1}{c|}{ Veg10 m } \\
\cline { 2 - 5 } & $b$ & $R^{2}$ & 0.14 & $R^{2}$ \\
\hline IBGN & 0.12 & $0.05^{*}$ & $0.04^{*}$ \\
\hline \multirow{2}{*}{ IPR } & -0.03 & 0.01 & -0.19 & $0.05^{*}$ \\
\cline { 2 - 5 } & \multicolumn{3}{|c|}{$N=113$ sites } & \multicolumn{3}{c}{$N=93$ sites } \\
\hline
\end{tabular}

\section{Table VI}

Fish-index (IPR) and macroinvertebrate index (IBGN) quantile regression results for riparian forest cover in $10 \mathrm{~m}$ and $30 \mathrm{~m}$ buffer in the hydro-ecoregions HER10 and HER9.

\begin{tabular}{|c|c|c|c|c|}
\hline & Value & Std. Error & $t$ value & $\operatorname{Pr}(>|t|)$ \\
\hline $\begin{array}{l}\text { HER10, } \\
\text { IPR, } 10 \mathrm{~m} \text { buffer } \\
\text { tau: } 0.5 \\
\text { tau: } 0.75\end{array}$ & $\begin{array}{l}-0.01 \\
-0.01\end{array}$ & $\begin{array}{l}0.005 \\
0.004\end{array}$ & $\begin{array}{l}-2.0 \\
-2.6\end{array}$ & $\begin{array}{l}0.045^{*} \\
0.011^{*}\end{array}$ \\
\hline $\begin{array}{l}\text { IPR, } 30 \mathrm{~m} \text { buffer } \\
\text { tau: } 0.5\end{array}$ & -0.02 & 0.008 & -2.2 & $0.029^{*}$ \\
\hline $\begin{array}{l}\text { IBGN, } 10 \mathrm{~m} \text { buffer } \\
\text { tau: } 0.5 \\
\text { tau: } 0.75\end{array}$ & $\begin{array}{l}0.02 \\
0.02\end{array}$ & $\begin{array}{l}0.010 \\
0.009\end{array}$ & $\begin{array}{l}2.3 \\
2.6\end{array}$ & $\begin{array}{l}0.023^{*} \\
0.009^{*}\end{array}$ \\
\hline $\begin{array}{l}\text { IBGN, } 30 \mathrm{~m} \text { buffer } \\
\text { tau: } 0.5 \\
\text { tau: } 0.75\end{array}$ & $\begin{array}{l}0.04 \\
0.04\end{array}$ & $\begin{array}{l}0.018 \\
0.016\end{array}$ & $\begin{array}{l}2.1 \\
2.7\end{array}$ & $\begin{array}{l}0.035^{\star} \\
0.007^{*}\end{array}$ \\
\hline $\begin{array}{l}\text { HER9 } \\
\text { IBGN, } 10 \text { m buffer } \\
\text { tau: } 0.5 \\
\text { tau: } 0.75\end{array}$ & $\begin{array}{l}1.61 \\
0.60\end{array}$ & $\begin{array}{l}1.277 \\
3.188\end{array}$ & $\begin{array}{l}1.3 \\
0.2\end{array}$ & $\begin{array}{l}0.211 \\
0.850\end{array}$ \\
\hline
\end{tabular}




\section{Table VII}

Nutrient (orthophosphates for HER9 and nitrite for HER10 sites) multiple regression parameter tests for riparian forest cover and discharge.

\begin{tabular}{|c|c|c|c|c|}
\hline \multicolumn{5}{|c|}{ Calcareous plains hydro-ecoregion HER9 orthophosphate mean $R^{2}=0.245$} \\
\hline & Estimate & Standard error & $t$ & $\operatorname{Pr}>|t|$ \\
\hline Veg10 m & -0.342 & 0.163 & -2.095 & 0.039 \\
\hline Discharge_spec & -0.268 & 0.158 & -1.694 & 0.093 \\
\hline Veg10 $m \times$ Discharge_spec & -0.047 & 0.212 & -0.221 & 0.826 \\
\hline \multicolumn{5}{|c|}{ Calcareous front hydro-ecoregion HER10 nitrite mean $R^{2}=0.235$} \\
\hline & Estimate & Standard error & $t$ & $\operatorname{Pr}>|t|$ \\
\hline Veg10 m & -0.475 & 0.239 & -1.985 & 0.051 \\
\hline Discharge_spec & -0.588 & 0.253 & -2.323 & 0.023 \\
\hline Veg10 $m \times$ Discharge_spec & 0.320 & 0.344 & 0.931 & 0.355 \\
\hline
\end{tabular}

interface. The extensive set of standardised monitoring surveys provides a stabilised network that enables analyses over larger scale patterns of ecological quality in river networks.

Here we focused solely on riparian forest cover. Other land use classes in the riparian corridor can also act as buffers (herbaceous semi-natural vegetation). However, to identify these kinds of vegetation unambiguously at this spatial scale from remote sensing data is still a challenge. At present this data is not available over these larger spatial scales.

\section{> HOW MUCH RIPARIAN FOREST IS REQUIRED?}

The detected relationship allows the determination of conditions for good ecological functioning of the riparian corridor. Not only were the responses consistent over the different selections and elements, they also showed similar response functions with respect to the different variables indicating the ecological status of the aquatic system. This enables the identification of boundary conditions for riparian forest cover to delineate good ecological status for the aquatic environment. The good and high status boundaries - the legal standards at national level according to the European Water Framework Directive - for the physicochemical variables and biotic integrity indices of the aquatic systems were consistently found to correspond to a narrow range of riparian forest cover values in all significant regressions. For the $10 \mathrm{~m}$ buffer, good status for physicochemical variables and biotic indices corresponded to $60 \%$ riparian forest cover, and high status to $70 \%$. For the $30 \mathrm{~m}$ buffer these boundaries were at $45 \%$ cover for good and $55 \%$ for high status of riparian forest. The quantile regression was even more reliable in making predictions, and corroborated the identified boundaries. The method of inflection point detection in the regression line pointed out the same boundary without using the standards for good physico-chemical and biotic status to infer the boundary. The detected responses were comparable to recent recordings of $54 \%$ forest cover as a boundary for the biotic integrity based on the Plecoptera genera (Tornblom et al., 2011). Like these authors, we detected a $55 \%$ boundary for the biotic integrity based on the fish community with the additive quantile regression approach (Figure 4).

The observed responses showed low explained variance and thus low predictive power for the regression functions ( $R^{2}$ values in Tables II and III between 0.11 and 0.22 ). However, these observed relationships give an indication that increasing riparian forest cover can significantly improve the rivers' purification potential and biotic integrity. Thus it can be classified as a 'noregret' restoration measure (European Commission, 2007), easily and immediately applicable without conflicting with more exhaustive integrated management programmes.

\section{> SINGLE VERSUS MULTI-STRESSOR ENVIRONMENTS}

In other parts of the world, much stronger relationships between the river's biotic integrity and the riparian corridor are found in strictly agricultural-forest landscapes, and are documented 
as consistent for single-pressure conditions. For smaller agricultural watersheds in North Carolina, $73 \%$ of the variance in fish and macroinvertebrate communities was explained by watershed and local riparian corridor characteristics (Stewart et al., 2001; Wilson et al., 2008; Arnaiz et al., 2011), whereas riparian forest as a single predictor explained $63 \%$ of the fish species assemblages in smaller headwater streams of agriculturally dominated catchments of a northern Great Plains ecoregion (Wilson et al., 2008). In our multi-stressor context, only up to $22 \%$ of the variance for nutrients (Table II) and $5 \%$ for biotic integrity metrics (Table V) are explained by riparian forest cover. An indication of the gradual impact of the multiple stressors intervening in the biotic response to the riparian corridor is also present in our analysis, when we compare the responses in the different ecoregions. Biotic responses were lower or absent for regions with a strong presence of multiple stressors. Ecoregion HER10 showed a lower multi-stressor state than the HER9 and showed more significant responses to the biological quality. Hence although certainly not a single-stressor environment, the HER10 is less influenced by multiple stressors.

In our selections, no difference in responses of nutrients was observed for the ecoregions. As we still found significant effects on nutrient conditions for strong multi-stressor environments, we can conclude that even though the effects are clearly more substantial in single-stressor environments - especially the effect on the biotic communities - in multi-stressor environments riparian forests can still positively influence the aquatic environment.

\section{ACKNOWLEDGEMENTS}

This work was supported by the French Ministry of the Environment (MEDDTL) and by the "Office National de l'Eau et des Milieux Aquatiques" (ONEMA). We are also grateful to the 6 water agencies and the 22 regional directions (DREAL) for the organisation of the monitoring networks and all the field operators that participated in the abiotic and biotic data collection.

\section{REFERENCES}

A.F.N.O.R., 1992. Essai des eaux. Determination de I'Indice Biologique Global Normalisé (IBGN). Association Française de Normalisation - norme homologuée T90-350:1-8.

Allan J.D., 2004. Landscapes and riverscapes: The Influence of Land Use on Stream Ecosystems. Annu. Rev. Ecol. Evol. Syst., 35, 257-284.

Arnaiz O.L., Wilson A.L., Watts R.J. and Stevens M.M., 2011. Influence of riparian condition on aquatic macroinvertebrate communities in an agricultural catchment in south-eastern Australia. Ecol. Res., $26,123-131$.

Astorga A., Heino J., Luoto M. and Muotka T., 2011. Freshwater biodiversity at regional extent: determinants of macroinvertebrate taxonomic richness in headwater streams. Ecography, 34, 705-713.

Bougon N. and Ferréol M., 2011. Physico-chimie soutenant la biologie. Typologie chimique nationale des cours d'eau. Rapport d'action 10, domaine QME. Pôle hydroécologie des cours d'eau Cemagref/Onema.

Bowes M.J., Ings N.L., McCall S.J., Warwick A., Barrett C., Wickham H.D., Harman S.A., Armstrong L.K., Scarlett P.M., Roberts C., Lehmann K. and Singer A.C. 2012 Nutrient and light limitation of periphyton in the River Thames: implications for catchment management. Sci. Total Envir., 434, 201-212.

Broadmeadow S.B., Jones J.G., Langford T.E.L., Shaw P.J. and Nisbet T.R., 2011. The influence of riparian shade on lowland stream water temperatures in southern England and their viability for brown trout. River Res. Appl., 27, 226-237.

Brooks S.S. and Lake P.S., 2007. River Restoration in Victoria, Australia: Change is in the Wind, and None too Soon. Restor. Ecol., 15, 584-591.

Brunke M., 2008. Hydromorphological indicators for the ecological status of fish inhabitating the lower trout region in streams in the North-German lowlands. Hydrologie Und Wasserbewirtschaftung, $52,234-244$. 
Cade B.S. and Noon B.R., 2003. A gentle introduction to quantile regression for ecologists. Front. Ecol. Environ., 1, 412-420.

Chandesris A., Mengin N., Malavoi J.R., Wasson J.G. and Souchon Y., 2008. SYRAH-CE: Système Relationnel d'Audit de l'Hydromorphologie des Cours d'Eau A relational, multi-scale system for auditing the hydro-morphology of running waters: diagnostic tool to help the WFD implementation in France. Page 4 in 4th international conference on river restoration, Venice, ITA.

Curie F., Ducharne A., Bendjoudi H. and Billen G., 2011. Spatialization of denitrification by river corridors in regional-scale watersheds: Case study of the Seine river basin. Physics and Chemistry of the Earth, 36, 530-538.

Death R.G. and Collier K.J., 2010. Measuring stream macroinvertebrate responses to gradients of vegetation cover: when is enough enough? Freshw. Biol., 55, 1447-1464.

Dodds W. and Oakes R., 2006. Controls on Nutrients Across a Prairie Stream Watershed: Land Use and Riparian Cover Effects. Environ. Manage., 37, 634-646.

Dodds W. and Oakes R., 2008. Headwater Influences on Downstream Water Quality. Environ. Manage., 41, 367-377.

Elosegi A., Diez J. and Mutz M., 2010. Effects of hydromorphological integrity on biodiversity and functioning of river ecosystems. Hydrobiologia, 657, 199-215.

European Commission, 2007. Adapting to climate change in Europe - options for EU action. Green Paper, COM(2007) 354 final.

Gauroy C. and Carluer N. (2011) Interpretation of data on pesticide residues in surface water in France, by grouping data within homogeneous spatial units. Knowl. Managt. Aquatic Ecosyst., 400, 04.

Ghermandi, A., V. Vandenberghe, L. Benedetti, W. Bauwens, P.A. Vanrolleghem (2009) Model-based assessment of shading effect by riparian vegetation on river water quality, Ecol. Eng., 35, 92-104.

Gregory S.V., Swanson F.J., McKee W.A. and Cummins K.W., 1991. An ecosystem perspective of riparian zones. Bioscience, 41, 540-551.

Hopkins R.L. and Whiles M.R., 2011. The importance of land use/land cover data in fish and mussel conservation planning. Ann. de Limnol. Int. J. Lim., 47, 199-209.

Hutchins, M.G., Johnson, A.C., Deflandre-Vlandas, A., Comber, S., Posen, P. \& Boorman, D. (2010) Which offers more scope to suppress river phytoplankton blooms: Reducing nutrient pollution or riparian shading? Science of The Total Environment, 408, 5065-5077.

Koenker R., 2010. Quantreg: Quantile Regression. R package version 4.50.

Leopold, L. B. 1994. A View of the River, Cambridge, Mass, Harvard University Press.

Lowrance R., Todd R., Fail J., Hendrickson O., Leonard R. and Asmussen L., 1984. Riparian forests as nutrient filters in agricultural watersheds. BioScience, 34, 374-377.

Lowrance R., Altier L.S., Newbold J.D., Schnabel R.R., Groffman P.M., Denver J.M., Correll D.L., Gilliam J.W., Robinson J.L., Brinsfield R.B., Staver K.W., Lucas W., Todd A.H., 1997. Water quality functions of riparian forest buffers in Chesapeake bay watersheds. Environ. Manage., 21, 687-712.

Mayer P.M., Reynolds S.K., McCutchen M.D. and Canfield T.J., 2007. Meta-analysis of nitrogen removal in riparian buffers. J. Environ. Qual., 36, 1172-1180.

Meador M.R. and Goldstein R.M., 2003. Assessing water quality at large geographic scales: Relations among land use, water physicochemistry, riparian condition, and fish community structure. Environ. Manage., 31, 504-517.

Montreuil O., Merot P. and Marmonier P., 2010. Estimation of nitrate removal by riparian wetlands and streams in agricultural catchments: effect of discharge and stream order. Freshw. Biol., 55, 2305-2318.

Newbold J.D., Herbert S., Sweeney B.W., Kiry P. and Alberts S.J., 2010. Water Quality Functions of a 15Year-Old Riparian Forest Buffer System1. Journal of the American Water Resources Association, 46, 299-310.

NOR, 2010. Arrêté du 25 janvier 2010 relatif aux méthodes et critères d'évaluation de l'état écologique, de l'état chimique et du potentiel écologique des eaux de surface pris en application des articles R. 212-10, R. 212-11 et R. 212-18 du code de l'environnement. NOR: DEVO1001032A.

Oberdorff T., Pont D., Hugueny B. and Porcher J.P., 2002. Development and validation of a fish-based index for the assessment of 'river health' in France. Freshw. Biol., 47, 1720-1734.

Palmer M., Allan J.D., Meyer J. and Bernhardt E.S., 2007. River Restoration in the Twenty-First Century: Data and Experiential Knowledge to Inform Future Efforts. Restor. Ecol., 15, 472-481. 
Palmer M.A., Menninger H.L. and Bernhardt E.S., 2010. River restoration, habitat heterogeneity and biodiversity: a failure of theory or practice? Freshw. Biol., 55, 205-222.

Parkyn S.M., Davies-Colley R.J., Halliday N.J., Costley K.J. and Croker G.F., 2003. Planted Riparian Buffer Zones in New Zealand: Do They Live Up to Expectations? Restor. Ecol., 11, 436-447.

Rios S. and Bailey R., 2006. Relationship between Riparian Vegetation and Stream Benthic Communities at Three Spatial Scales. Hydrobiologia, 553, 153-160.

Sandin L. and Solimini A.G., 2009. Freshwater ecosystem structure-function relationships: From theory to application. Freshw. Biol., 54, 2017-2024.

Santoul F., Cayrou J., Mastrorillo S. and Céréghino R., 2005. Spatial patterns of the biological traits of freshwater fish communities in south-west France. J. Fish Biol., 66, 301-314.

Sauquet E. and Catalogne C. (2011) Comparison of catchment grouping methods for flow duration curve estimation at ungauged sites in France. Hydrology and Earth System Sciences, 15, 2421-2435.

Snelder T.H., Lamouroux N., Leathwick J.R., Pella H., Sauquet E. and Shankar U. (2009) Predictive mapping of the natural flow regimes of France. J. Hydrol., 373, 57-67.

Statsoft, 2010. STATISTICA data analysis software system, version 10 Tulsa: Statsoft Inc.

Stewart J.S., Wang L.Z., Lyons J., Horwatich J.A. and Bannerman R., 2001. Influences of watershed, riparian-corridor, and reach-scale characteristics on aquatic biota in agricultural watersheds. Journal of the American Water Resources Association, 37, 1475-1487.

Storey R.G. and Cowley D.R., 1997. Recovery of three New Zealand rural streams as they pass through native forest remnants. Hydrobiologia, 353, 63-76.

Suren A.M. and McMurtrie S., 2005. Assessing the effectiveness of enhancement activities in urban streams: II. Responses of invertebrate communities. River Res. Appl., 21, 439-453.

Tornblom J., Degerman E. and Angelstam P., 2011. Forest proportion as indicator of ecological integrity in streams using Plecoptera as a proxy. Ecological Indicators, 11, 1366-1374.

Van Looy K., Meire P. and Wasson J.G., 2008. Including Riparian Vegetation in the Definition of Morphologic Reference Conditions for Large Rivers: A Case Study for Europe's Western Plains. Environ. Manage., 41, 625-639.

Wallace J.B., Eggert S.L., Meyer J.L. and Webster J.R., 1997. Multiple Trophic Levels of a Forest Stream Linked to Terrestrial Litter Inputs. Science, 277, 102-104.

Wang X., Wang Q., Yang S., Zheng D., Wu C. and Mannaerts C.M., 2011. Evaluating nitrogen removal by vegetation uptake using satellite image time series in riparian catchments. Science of The Total Environment, 409, 2567-2576.

Wasson J.G., Chandesris A., Pella H., Blanc L., 2002. Typology and reference conditions for surface water bodies in France: the hydro-ecoregion approach. TemaNord, 566, 37-41.

Wasson J.G., Villeneuve B., Ital A., Murray-Bligh J., Dobiasova M., Bacikova S., Timm H., Pella H., Mengin N. and Chandesris A., 2010. Large-scale relationships between basin and riparian land cover and the ecological status of European rivers. Freshw. Biol., 55, 1465-1482.

Weller D., Baker M.E. and Jordan T.E., 2012. Effects of riparian buffers on nitrate concentrations in watershed discharges: new models and management implications. Ecological Applications, in press.

Wenger S., 1999. Review of Scientific Literature on Riparian Buffer Width, Extent and Vegetation. Office of Public Service \& Outreach Institute of Ecology University of Georgia.

Wilson H.F. and Xenopoulos M.A., 2008. Landscape influences on stream fish assemblages across spatial scales in a northern Great Plains ecoregion. Can. J. Fish. Aqua. Sci., 65, 245-257. 